\title{
Accessory Gvp Proteins Form a Complex During Gas Vesicle Formation of Haloarchaea
}

\author{
Kerstin Völkner, Alisa Jost and Felicitas Pfeifer* \\ Microbiology and Archaea, Department of Biology, Technical University of Darmstadt, Darmstadt, Germany
}

Halobacterium salinarum forms gas vesicles consisting of a protein wall surrounding a gas-filled space. The hydrophobic 8-kDa protein GvpA is the major constituent of the ribbed wall, stabilized by GvpC at the exterior surface. In addition, eight accessory Gvp proteins are involved, encoded by gvpFGHIJKLM that are co-transcribed in early stages of growth. Most of these proteins are essential, but their functions are not yet clear. Here we investigate whether GvpF through GvpM interact. Pull-down experiments performed in Haloferax volcanii with the cellulose-binding-domain as tag suggested many interactions, and most of these were supported by the split-GFP analyses. The

OPEN ACCESS

Edited by:

Harold J. Schreier,

University of Maryland, Baltimore County, United States

Reviewed by:

Jerry Eichler,

Ben-Gurion University of the Negev,

Israel

Aharon Oren

Hebrew University of Jerusalem, Israel

*Correspondence:

Felicitas Pfeifer

pfeifer@bio.tu-darmstadt.de

Specialty section:

This article was submitted to Microbial Physiology and Metabolism,

a section of the journal

Frontiers in Microbiology

Received: 28 September 2020

Accepted: 23 October 2020

Published: 12 November 2020

Citation:

Völkner $K$, Jost $A$ and Pfeifer F (2020) Accessory Gvp Proteins Form

a Complex During Gas Vesicle

Formation of Haloarchaea.

Front. Microbiol. 11:610179.

doi: 10.3389/fmicb.2020.610179 latter study indicated that GvpL attracted all other accessory Gvp, and the related GvpF bound besides GvpL also GvpG, GvpH and Gvpl. A strong interaction was found between GvpH and Gvpl. GvpG showed affinity to GvpF and GvpL, whereas GvpJ, GvpK and GvpM bound GvpL only. Using GvpA for similar analyses yielded GvpF as the only interaction partner. The contact site of GvpF was confined to the N-terminal half of GvpA and subsequently mapped to certain amino acids. Taken together, our results support the idea that the accessory Gvp form a complex early in gas-vesicle assembly attracting GvpA via GvpF.

Keywords: protein-protein interaction, split-GFP, protein network, cellulose binding domain, Haloferax volcanii, Halobacterium salinarum

\section{INTRODUCTION}

Halophilic archaea (haloarchaea) thrive in hypersaline environments such as salt lakes or salterns containing up to $30 \% \mathrm{NaCl}$. They adapt to these salty conditions by maintaining a similarly high $\mathrm{KCl}$ concentration in the cytoplasm. The haloarchaea Halobacterium salinarum and Haloferax mediterranei produce gas vesicles allowing the cells to float to the surface of the brine. These gasfilled vesicles consist of a wall exclusively formed by proteins. Major component is the hydrophobic, 8-kDa GvpA aggregating into a low-pitch helix seen by transmission electron microscopy as $4.6 \mathrm{~nm}$ wide ribs running perpendicular to the long axis of the gas vesicle (Walsby, 1994; Offner et al., 1998; Pfeifer, 2012). The protein wall is stabilized on the exterior surface by the second structural protein, GvpC (Englert and Pfeifer, 1993). Gases are able to diffuse in and out, presumably via small holes in the wall. Water vapor might enter the hollow space, but is unable to precipitate because of the hydrophobic interior surface of the wall (Walsby, 1994). Electron microscopic studies of haloarchaeal cells indicate small bicones already filled with gas in early stages of growth; these bicones are enlarged to spindle- or cylinder-shaped structures. The final diameter of the 
haloarchaeal gas vesicle is $200-250 \mathrm{~nm}$; and the cylindershaped structures can grow as long as $2 \mu \mathrm{m}$ (Walsby, 1994; Knitsch et al., 2017).

Gas vesicles of haloarchaea are encoded by a gene cluster consisting of 14 gas vesicle protein $(g v p)$ genes arranged as gvpACNO and gvpDEFGHIJKLM, and eight of these genes are essential to produce a gas-filled particle as determined in Haloferax volcanii transformants (Englert et al., 1992; Offner et al., 2000). This moderately halophilic haloarchaeon is easy to transform, grows faster than Hbt. salinarum and lacks all of the $g v p$ genes. The six non-essential Gvp proteins are the surface-attached GvpC, the two regulatory proteins GvpD and GvpE (Krüger et al., 1998; Zimmermann and Pfeifer, 2003; Hofacker et al., 2004), and the proteins GvpH, GvpI and GvpN (Offner et al., 2000). The absence of GvpC in Hfx. volcanii $\Delta \mathrm{C}$ transformants (the $\Delta \mathrm{C}$ construct contains except $g v p C$ all gvp genes) leads to long and weak gas vesicles with altering diameters (Offner et al., 1996), whereas the absence of GvpD and GvpE causes a low expression of the gvp gene cluster. In the case of GvpH and GvpI altered gas vesicle structures are observed. $\Delta \mathrm{H}$ transformants produce weaker gas vesicles of wild type shape, whereas extremely long and cylinder-shaped gas vesicles are found in $\Delta \mathrm{I}$ transformants. The lack of GvpN leads to small bicones that are not enlarged (Offner et al., 2000). A deletion of any other $g v p$ gene in the cluster leads to gas vesicle negative $\left(\mathrm{Vac}^{-}\right.$) transformants (Offner et al., 2000). Isolated gas vesicles cannot be disintegrated into their protein constituents and separated by sodium dodecyl sulfate polyacrylamide gel electrophoresis (SDS-PAGE); only GvpC is washed off and separated on the gel (Englert and Pfeifer, 1993). Aggregates of the hydrophobic GvpA dissolve in $80 \%$ formic acid only, and dialysis to remove the formic acids leads to amorphous precipitates of GvpA (Belenky et al., 2004). The protein constituents of the gas vesicles were determined by MS/MS-based proteome analyses or immunological methods (Shukla and DasSarma, 2004; Chu et al., 2011). Except for GvpD, GvpE, and GvpK, all Gvp proteins are present in gas vesicle preparations suggesting that they are constituents of the wall or are attached to the structure during gas-vesicle assembly.

The transcript encoding the accessory gas vesicle proteins GvpF through GvpM occurs in early exponential growth, implying that these proteins are required in early stages of gasvesicle assembly (Offner and Pfeifer, 1995). Putative interactions of GvpM have been studied by affinity chromatography with His-tagged Gvp and Ni-NTA matrices, and the results suggest that GvpM is able to bind GvpH, GvpJ and GvpL, but not GvpG (Tavlaridou et al., 2014). For these analyses, His Gvp proteins were synthesized in Escherichia coli, purified under denaturing conditions and refolded in high salt solutions. Haloarchaea require $15-30 \% \mathrm{NaCl}$ for growth, and adapt by maintaining a similarly high $\mathrm{KCl}$ concentration in the cytoplasm. The haloarchaeal proteins are usually adapted to these salt concentrations and often denature in low salt solutions. Thus, the purification of these proteins from E. coli in low-salt solutions might have influenced the protein structure and interaction. Also, other histidine-rich haloarchaeal proteins bind non-specifically to the Ni-NTA or Ni-sepharose matrices used for the binding of His-tagged Gvp to select putative binding partners and complicate the analysis.

To study putative interactions of Gvp proteins in high salt, we recently adapted the split-GFP method (Ghosh et al., 2000; Magliery et al., 2005) to high salt solutions and studied proteinprotein interactions in Hfx. volcanii transformants (Winter et al., 2018). We used a derivative of the salt-adapted green fluorescent protein smRS-GFP (Reuter and Maupin-Furlow, 2004) with higher fluorescence, mGFP2 (Born and Pfeifer, 2019). The mGFP2 protein was split in the $\mathrm{N}$ - and C-terminal fragments (NGFP and CGFP) that were fused to the two proteins of interest. Both fragments do not assemble in trans, but will form a fluorescent GFP when the two fusion partners interact. The fluorescence of the transformants can be easily quantified (Winter et al., 2018). For each protein, four different N/CGFP fusions (N- or CGFP fused $\mathrm{N}$ - or C-terminally) are produced and eight combinations tested per protein pair to exclude putative steric hindrances for the assembly of GFP. Using this method, the interaction of GvpL/GvpM was confirmed, and the interaction site in GvpM confined to the N-terminal 25-amino acid (aa) (Winter et al., 2018). GvpM also interacted with GvpF and GvpH, and both proteins bound to the C-terminal 25 aa of GvpM (Winter et al., 2018).

In this report, we present a comprehensive study on the interactions of the accessory proteins GvpF through GvpM. Two different methods were applied, i.e., pull-down experiments with the cellulose-binding domain, $\mathrm{CBD}$, and the in vivo analysis by split-GFP. The cellulose binding domain derives from Clostridium thermocellum and is part of the CipB protein (Poole et al., 1992; Morag et al., 1995). Proteins tagged with CBD can be selected by cellulose in high salt solutions (Ortenberg and Mevarech, 2000; Irihimovitch and Eichler, 2003; Schlesner et al., 2012). The ${ }_{C B D}$ Gvp proteins and their putative Gvp binding partners were selected from lysates of $H f x$. volcanii producing both bait and prey proteins. Each of the accessory Gvp proteins interacted with other Gvp, and ${ }_{\mathrm{CBD}} \mathrm{GvpM}$ attracted all of them at once. In addition, each protein pair was tested by splitGFP in $H f x$. volcanii transformants, and an interaction network was deduced. GvpL and GvpF had several interaction partners, whereas $\mathrm{GvpH}$ and GvpI bound each other and also interacted with GvpF and GvpL. In addition, the major gas vesicle structural protein GvpA was tested by split-GFP for interactions with these accessory proteins, and GvpF appeared to be the only binding partner. More detailed analyses with fragments of GvpA and variants of GvpA carrying single substitutions confined the interaction site of GvpF in GvpA.

\section{MATERIALS AND METHODS}

\section{Strains and Cultivation Conditions}

The Escherichia coli strains One Shot Top10 (Invitrogen by Life Technologies) and GM1674 ( $\left.\mathrm{dam}^{-}\right)$(Palmer and Marinus, 1994) were grown in Luria-Bertani media at $37^{\circ} \mathrm{C}$ overnight. For the selection of transformants, $100 \mu \mathrm{g} / \mathrm{mL}$ ampicillin was added. The haloarchaeon Haloferax volcanii WR340 was grown in salt media containing $3 \mathrm{M} \mathrm{NaCl}, 150 \mathrm{mM} \mathrm{MgSO}_{4}, 50 \mathrm{mM} \mathrm{KCl}$, 
0.05\% (w/v) $\mathrm{CaCl}_{2}, 25 \mathrm{mM}$ Tris- $\mathrm{HCl} \mathrm{pH} 7.2,10 \mathrm{nM} \mathrm{MnCl}_{2}$, $0.5 \%(\mathrm{w} / \mathrm{v})$ tryptone, $0.3 \%(\mathrm{w} / \mathrm{v})$ yeast extract and $0.02 \%(\mathrm{w} / \mathrm{v})$ histidine. For solid media, $1.8 \%(\mathrm{w} / \mathrm{v})$ agar was added. To select Hfx. volcanii transformants, $6 \mu \mathrm{g} / \mathrm{mL}$ mevinolin (for selection of $\mathrm{pWL}_{\mathrm{fdx}}$ ) and $0.2 \mu \mathrm{g} / \mathrm{mL}$ novobiocin (for selection of pJAS35) were added. Cultures on solid medium were incubated at $42^{\circ} \mathrm{C}$ for 3-7 days in a humid atmosphere. Liquid cultures were grown for 3-5 days on a shaker at $180 \mathrm{rpm}$ and $42^{\circ} \mathrm{C}$. Cultures forming GFP were initially incubated at $37^{\circ} \mathrm{C}$ for $24 \mathrm{~h}$ before they were transferred to $30^{\circ} \mathrm{C}$ overnight to enhance fluorescence, always shaking at $180 \mathrm{rpm}$.

\section{Vector Construction and Transformation of Hfx. volcanii}

The split-GFP shuttle vectors pJAS-NGFP-Nterm and -Cterm, as well as pWL-CGFP-Nterm and -Cterm have been described previously (Winter et al., 2018). They are based on the two compatible vector plasmids pJAS35 (Pfeifer et al., 1994) and $\mathrm{pWL}_{\mathrm{fdx}}$ (Scheuch and Pfeifer, 2007). The salt adapted mGFP2 is split between the residues 157 and 158, resulting in the NGFP and CGFP fragments. Nterm describes a fusion of the respective $m g f p 2$ fragment to the $5^{\prime}$-terminus of the gene of interest, whereas Cterm stands for a fusion at the $3^{\prime}$-terminus. The respective $m g f p 2$ fragments plus linker region are present in these vectors. The size of the linker encoded by the pJAS-derived shuttle vector is 14 aa [(GGSGSGS $)_{2}$ ], whereas the linker derived from the $\mathrm{pWL}_{\mathrm{fdx}}$ vector is 16 aa long [(GGSG) $)_{4}$ (Winter et al., 2018). The $g v p$ reading frame under investigation was fused to $n g f p$ or $c g f p$ by inserting the respective fragment in these vector plasmids. The $g v p$ reading frames were amplified by PCR using the p-vac region as template (containing the $14 \mathrm{gvp}$ genes of $\mathrm{Hbt}$. salinarum PHH1; Englert et al., 1992), and oligonucleotides including the desired restriction site for insertion (Supplementary Table 1). The NcoI-gvp-BlpI fragments amplified were inserted in pJASNGFP-Nterm or pJAS-NGFP-Cterm. For the insertion of $g v p$ in pWL-CGFP-Nterm, BamHI and KpnI sites were used, and $\mathrm{NcoI}$ and BamHI for the insertion in pWL-CGFP-Cterm. In some cases, BspHI ( $g v p F$, gvpI gvpJ, gvpL) or PciI ( $g v p G)$, was used instead of NcoI. Due to the presence of a KpnI site in $g v p H$, the amplified $g v p H$ fragment was blunt-ended inserted in pWL-CGFP-Nterm.

For pull-down assays of CBD-tagged proteins, the shuttle vector $\mathrm{pCBD}$ was used (Supplementary Figure 1). The $c b d$ reading frame encodes the cellulose binding domain of the CipB protein from Clostridium thermocellum (Poole et al., 1992; Morag et al., 1995). The $c b d$ reading frame was amplified from plasmid pWL-CBD-sec11b (Fine et al., 2006) and inserted in $\mathrm{pWL}_{\mathrm{fdx}}$ via NcoI and KpnI. Two additional cloning sites are present (BamHI, $X b a \mathrm{I}$ ) allowing the insertion of the respective gvp reading frame upstream or downstream of $c b d$ [NcoI and BamHI upstream of

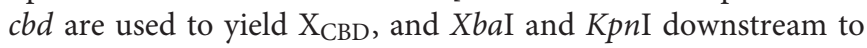
yield ${ }_{\mathrm{CBD}} \mathrm{X}$ (with $\mathrm{X}=\mathrm{GvpF}, \mathrm{G}, \mathrm{H}, \mathrm{I}, \mathrm{J}, \mathrm{K}, \mathrm{L}$, or $\mathrm{M}$ )]. The expression of the respective gene fusion is under control of the strong ferredoxin promoter, $P_{f d x}$ (Pfeifer et al., 1994). The $g v p$ sequences were amplified using $\mathrm{p}$-vac as template. The oligonucleotides used are listed in Supplementary Table 1. For the construction of
pF-L ${ }^{\mathrm{ex}}$, the $g v p F G H I J K L$ reading frames of $\mathrm{p}$-vac were amplified

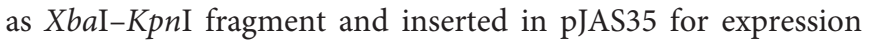
under $P_{f d x}$ control.

In all cases, the correct insertion was verified by DNA sequence analysis. To avoid a restriction barrier in Hfx. volcanii WR340, the plasmid DNA was demethylated by passage through E. coli GM1674 (dam-) (Palmer and Marinus, 1994). Hfx. volcanii was transformed simultaneously with the two vector plasmids as described previously (Pfeifer and Ghahraman, 1993). In each case, the presence of both plasmids was confirmed by $\mathrm{PCR}$, and the presence of the respective Gvp protein determined by Western analysis.

\section{Western Analysis}

To verify the expression of $g v p-g f p$ or $g v p$-cbd fusions, total protein was isolated from $50 \mathrm{~mL}$ cultures of the transformants in the late exponential growth phase. Cells were harvested by centrifugation $\left(2,370 \times g, 30 \mathrm{~min}, 4^{\circ} \mathrm{C}\right)$ and re-suspended in $5 \mathrm{~mL}$ lysis buffer (2.5 M KCl, $50 \mathrm{mM} \mathrm{MgCl}_{2}, 1 \mathrm{mM} \mathrm{EDTA,} \mathrm{5 \%} \mathrm{(v/v)}$ glycerol, 50 mM Tris-HCl pH 8.0) + DNaseI (0.1 mg/mL). Cells were lysed by sonification on ice. The lysate was cleared from cell debris by centrifugation and dialyzed against $10 \mathrm{mM}$ Tris- $\mathrm{HCl}$ pH 7.2 overnight at $20^{\circ} \mathrm{C}$ to eliminate salts. $20 \mu \mathrm{g}$ of total protein was separated by SDS-PAGE (Schägger and von Jagow, 1987) and transferred to a PVDF membrane (Roti Fluoro PVDF, Carl Roth) using a Semidry-Blotter (PerfectBlue ${ }^{\mathrm{TM}}, 30 \mathrm{~min}, 2 \mathrm{~mA}$ ). The membrane was dried for one hour, reactivated with $100 \%$ (v/v) methanol and washed two times in PBS (137 $\mathrm{mM} \mathrm{NaCl}$, $2.7 \mathrm{mM} \mathrm{KCl}, 10 \mathrm{mM} \mathrm{Na}_{2} \mathrm{HPO}_{4}, 2 \mathrm{mM} \mathrm{KH}_{2} \mathrm{PO}_{4}$ ) before blocking for an hour with Odyssey Blocking Buffer (Licor). The membrane was incubated with the respective antiserum raised against GvpF, GvpG, GvpH, GvpI, GvpJ, GvpK, GvpL, GvpM, or isolated gas vesicles (to detect GvpA). The membrane was washed four times in PBS $+0.1 \%(\mathrm{v} / \mathrm{v})$ Tween 20 , incubated with the secondary antibodies labeled with IRDye $800 \mathrm{CW}$ (Licor) for $1-2 \mathrm{~h}$ at $20^{\circ} \mathrm{C}$, and washed four times for $5 \mathrm{~min}$ in PBS $+0.1 \%$ (v/v) Tween 20 . Excessive Tween 20 was removed by washing the membrane with PBS. The fluorophore coupled to the secondary antibody is detectable at $800 \mathrm{~nm}$ with the Odyssey Fc Imager (Licor).

\section{Quantitation of GFP Fluorescence}

The fluorescence of $H f x$. volcanii transformants was measured to determine the formation of fluorescent GFP as a result of an interaction of the two fused proteins of interest. Transformants were grown as described to $\mathrm{OD}_{600 \mathrm{~nm}} 1.5-2$. Two $\mathrm{mL}$ of the culture were harvested $\left(2 \mathrm{~min}, 9,600 \mathrm{x}, 20^{\circ} \mathrm{C}\right)$, the cells washed in $1 \mathrm{~mL}$ basal salts $\left(3 \mathrm{M} \mathrm{NaCl}, 150 \mathrm{mM} \mathrm{MgSO}_{4}, 50 \mathrm{mM} \mathrm{KCl}\right.$ ), and re-suspended in $500 \mu \mathrm{L}$ basal salts. To investigate equal amounts of cells, the OD value was adjusted to $\mathrm{OD}_{600 \mathrm{~nm}} 1$, and $300 \mu \mathrm{L}$ of the culture transferred into a microtiter dish. For each Gvp protein combination, two biological and three technical replicates were investigated. The fluorescence was measured (Phosphorimager FLA-5000 and the software Fujifilm science lab image gauge ver. 4.24), and the fluorescence intensity obtained in light absorbing units (LAU) per $\mathrm{mm}^{2}$. The relative fluorescence, rf, was calculated as described (Winter et al., 2018). The $p$-value was determined by Student's T-test. 


\section{Affinity Chromatography Using CBD-Tagged Proteins}

Each accessory Gvp was fused to the cellulose binding domain, $\mathrm{CBD}$, at the $\mathrm{N}$ - or $\mathrm{C}$-terminus $\left(\mathrm{CBD} \mathrm{X}\right.$ or $\mathrm{X}_{\mathrm{CBD}}$ ) and lysates of the respective ${ }_{\mathrm{CBD}} \mathrm{X} / \mathrm{Y}$ transformants were tested in pulldown experiments ( $\mathrm{X}, \mathrm{Y}=$ any accessory $\mathrm{Gvp})$. In the case of $\mathrm{CBD}_{\mathrm{C}} \mathrm{M}$, also ${ }_{\mathrm{CBD}} \mathrm{M} / \mathrm{pF}-\mathrm{L}^{\mathrm{ex}}$ transformants were tested. For each pull-down experiment, $400 \mathrm{~mL}$ cultures were grown at $37^{\circ} \mathrm{C}, 180 \mathrm{rpm}$ to the late exponential growth phase. The cells were harvested $\left(12,210 \times \mathrm{g}, 20 \mathrm{~min}, 4^{\circ} \mathrm{C}\right)$, and resuspended in $5 \mathrm{~mL}$ lysis buffer (2.5 M KCl, $50 \mathrm{mM} \mathrm{MgCl} 2,1 \mathrm{mM}$ EDTA, 5\% (v/v) glycerol, $50 \mathrm{mM}$ Tris- $\mathrm{HCl} \mathrm{pH} \mathrm{8.0)}$ plus DNaseI $(0.1 \mathrm{mg} / \mathrm{mL})$. The cells were lysed by ultrasound (Branson Sonifier 250, duty cycle: $55 \%$, output control: $5,2 \mathrm{~min}$ ) and the suspension centrifuged for $20 \mathrm{~min}$ at $2,370 \times g, 4^{\circ} \mathrm{C}$. The soluble protein fraction $(7 \mathrm{~mL})$ was incubated with $1 \mathrm{~mL}$ of a $10 \%(\mathrm{w} / \mathrm{v})$ cellulose suspension (Avicel PH-101, Sigma Aldrich) for $30 \mathrm{~min}$ at room temperature on an overhead rotator. The suspension was centrifuged $(2,370 \times g$, $30 \mathrm{~s}$ ), the supernatant removed and the resulting cellulose pellet with bound proteins resuspended in $600 \mu \mathrm{L}$ washing buffer $(2.5$ $\mathrm{M} \mathrm{KCl}, 50 \mathrm{mM}$ Tris- $\mathrm{HCl} \mathrm{pH}$ 8.0). The solution was transferred to an empty Mobicol column (Mobitec) and centrifuged $(1,000 \times g$, $1 \mathrm{~min}$ ), followed by six washing steps with $600 \mu \mathrm{l}$ washing buffer. For protein elution, the cellulose was resuspended in $500 \mu \mathrm{L}$ $100 \%$ ethylene glycol, incubated for $1 \mathrm{~min}$ at room temperature and centrifuged at $4,700 \times g, 5 \mathrm{~min}$. All fractions were dialyzed against $10 \mathrm{mM}$ Tris-HCl, $\mathrm{pH} 7.2$ overnight. For the analysis of proteins, $15 \mu \mathrm{L}$ of each fraction were separated by SDS-PAGE (Schägger and von Jagow, 1987). The Gvp proteins were detected by Western analysis using the respective antisera.

\section{RESULTS}

Two different methods were applied to investigate proteinprotein interactions. The first approach was pull-down experiments using the cellulose-binding domain as tag, and the second approach was split-GFP to identify interaction partners in vivo.

\section{Pull-down Experiments Using the Cellulose Binding Domain}

Putative interactions of the accessory proteins GvpF through GvpM were investigated by pull-down experiments using the cellulose binding domain, $\mathrm{CBD}$, allowing tagged proteins to bind cellulose at high salt concentrations $(2-3 \mathrm{M} \mathrm{KCl})$ (Ortenberg and Mevarech, 2000; Irihimovitch and Eichler, 2003; Schlesner et al., 2012). CBD was fused to the N-or C-terminus of each accessory Gvp using the vector plasmid pCBD (Supplementary Figure 1). The resulting ${ }_{\mathrm{CBD}} \mathrm{X}$ or $\mathrm{X}_{\mathrm{CBD}}$ constructs $(\mathrm{X}=$ any accessory GvpF through GvpM) were used to transform Haloferax volcanii WR340. To test whether the CBD-fusion proteins can be indeed purified in $2 \mathrm{M} \mathrm{KCl}$, lysates of the respective ${ }_{\mathrm{CBD}} \mathrm{X}$ transformants were mixed with cellulose to bind the CBD-tagged Gvp, and the elution fractions were investigated by SDS-PAGE as well as Western analysis using antisera raised against the various Gvp proteins (Supplementary Figure 2). Except for GvpJ and GvpM, the accessory Gvp were isolated in decent amounts (Table 1), and well visible in the Coomassie-stained gels (Supplementary Figure 2). GvpJ and GvpM were obtained in much lower amounts, presumably due to their hydrophobic nature and tendency to aggregate. Aggregates of GvpJ and GvpM might be present in the solid fraction of the cell extracts, and the addition of the detergents DDM (n-dodecyl- $\beta$-D-maltoside) or OGP (octyl$\beta$-D-glucopyranoside) to the lysate and wash buffer slightly improved the presence of these proteins in the soluble fraction (Table 1). All of the accessory Gvp proteins including GvpJ and GvpM were detectable by Western analysis (Supplementary Figure 2). A smear of larger bands is always detectable with GvpJ, indicative of its ability to aggregate (Supplementary Figure 2). Thus, each of the ${ }_{C B D}$ Gvp proteins was selected and could be purified. To ensure that the untagged Gvp interacted neither with the cellulose matrix nor with CBD, transformants were produced harboring the plasmids $\mathrm{pCBD}$ (without $g v p$ ) and $\mathrm{pX}^{\mathrm{ex}}(g v p X-$ pJAS35 expressing any $g v p$ without $c b d$ fusion). None of the Gvp proteins tested was detectable in the respective elution fraction demonstrating that none of them bound to cellulose or to CBD itself (data not shown).

The CBD-tagged Gvp proteins were used as bait and tested for the selection of a putative Gvp interaction partner produced in the same cell. The first protein pair tested was GvpL/GvpM, where an interaction has been demonstrated using His-tagged Gvp proteins. GvpL or GvpM carried CBD fused to the N- or C-terminus ( $\mathrm{CBD}, \mathrm{L}, \mathrm{L}_{\mathrm{CBD}}$ or ${ }_{\mathrm{CBD}} \mathrm{M}, \mathrm{M}_{\mathrm{CBD}}$ ), and the combinations ${ }_{\mathrm{CBD}} \mathrm{L} / \mathrm{M}, \mathrm{L}_{\mathrm{CBD}} / \mathrm{M},{ }_{\mathrm{CBD}} \mathrm{M} / \mathrm{L}$ and $\mathrm{M}_{\mathrm{CBD}} / \mathrm{L}$ were analyzed. Lysates of the $\mathrm{CBD}_{\mathrm{BD}} \mathrm{L} / \mathrm{M}$ and $\mathrm{L}_{\mathrm{CBD}} / \mathrm{M}$ transformants were tested for the presence of GvpM, and monomers and dimers of this protein were identified by Western analysis (Supplementary Figure 3). Also, GvpL was present in the elution fractions of the $\mathrm{CBD}_{\mathrm{MD}} / \mathrm{L}$ and $\mathrm{M}_{\mathrm{CBD}} / \mathrm{L}$ transformants indicating that GvpL bound GvpM (Supplementary Figure 3). These results

TABLE 1 | Amount of $\mathrm{CBD}$ Gvp recovered from a $400 \mathrm{ml}$ culture by CBD.

\begin{tabular}{lc}
\hline Protein & Amount in $\boldsymbol{\mu} \mathbf{g}^{*}$ \\
\hline CBD $F$ & $146 \pm 44$ \\
CBD G & $307 \pm 41$ \\
CBD $H$ & $417 \pm 86$ \\
CBDl & $142 \pm 18$ \\
CBDJ & $23 \pm 5$ \\
CBD K & $214 \pm 35$ \\
CBD $L$ & $484 \pm 21$ \\
CBDM & $13 \pm 2$ \\
CBDJ (1.4 mM DDM) & $67 \pm 14$ \\
CBDJ (10.4 mM DDM) & $132 \pm 20$ \\
CBDJ (60 mm OGP) & $90 \pm 9$ \\
CBDM (1.4 mM DDM) & $14 \pm 0$ \\
CBDM (10.4 mM DDM) & $33 \pm 14$ \\
CBDM (60 mM OGP) & $18 \pm 5$
\end{tabular}

*The standard deviation was calculated from two biological and three technical replicates. 
confirmed the GvpL/GvpM interaction already seen using the respective His-tagged Gvp proteins and a Ni-NTA matrix for affinity chromatography (Tavlaridou et al., 2014).

Similar pull-down experiments with CBD were performed with all other accessory Gvp proteins. The respective Hfx. volcanii transformants always carried two constructs, one for the bait protein $(\mathrm{CBD} X)$, and one for the prey GvpY (with $\mathrm{X}, \mathrm{Y}=\mathrm{F}, \mathrm{G}, \mathrm{H}$, $\mathrm{I}, \mathrm{J}, \mathrm{K}, \mathrm{L}$, or $\mathrm{M})$. Both reading frames encoding bait and prey were expressed under $P_{f d x}$ promoter control to ensure a similarly high expression. Not all possible interactions were performed in both ways $(\mathrm{CBD} X+\mathrm{Y}$ and $\mathrm{CBD} Y+\mathrm{X})$, since protein interactions were already found with one protein pair. The results of these studies are presented in Figure $\mathbf{1}$ and summarized Table 2. The Western blots in Figure $\mathbf{1}$ are arranged according to the antiserum used to detect the prey protein. Using ${ }_{\mathrm{CBD}} \mathrm{X}$ to select GvpM yielded monomeric GvpM with $\mathrm{CBD} H$, and monomers as well as dimers with ${ }_{\mathrm{CBD}}$ F, ${ }_{\mathrm{CBD}} \mathrm{G},{ }_{\mathrm{CBD}} \mathrm{J}, \mathrm{CBD}_{\mathrm{C}} \mathrm{K}$, and ${ }_{\mathrm{CBD}} \mathrm{L}$ (Figure 1). Dimers and multimers of GvpM were observed with $\mathrm{CBD}^{\mathrm{I}}$ (Figure 1). Thus, GvpM was pulled-down in all these cases. GvpL was selected by ${ }_{\mathrm{CBD}} \mathrm{F}$, but the results obtained with $\mathrm{CBD}_{\mathrm{H}} \mathrm{H}$ or $\mathrm{CBD}$ I were ambiguous (Figure 1). However, when ${ }_{\mathrm{CBD}} \mathrm{L}$ was used as bait, GvpM, GvpK, GvpJ, or GvpG were selected again suggesting that all these accessory Gvp bound GvpL. Also, GvpK interacted with any of the accessory Gvp, since $\mathrm{CBD}_{\mathrm{F}}$ through ${ }_{\mathrm{CBD}} \mathrm{J}$ and ${ }_{\mathrm{CBD}} \mathrm{L}$ pulleddown GvpK, and $\mathrm{CBD}_{\mathrm{K}}$ recovered GvpM. Monomers of GvpJ were selected by ${ }_{\mathrm{CBD}} \mathrm{X}$, but a smear including additional GvpJ multimers were found with ${ }_{\mathrm{CBD}} \mathrm{F}, \mathrm{CBD}_{\mathrm{CB}} \mathrm{H}, \mathrm{CBD}_{\mathrm{CBD}} \mathrm{L}$, or ${ }_{\mathrm{CBD}} \mathrm{M}$ (Figure 1). GvpI was only used as bait, and $\mathrm{CBD} \mathrm{I}$ pulled-down any of the accessory Gvp proteins. It is interesting to note that $\mathrm{CBD} I$ often induced the formation of larger oligomers, especially with GvpM, GvpK or GvpJ as prey. GvpH was selected by ${ }_{\mathrm{CBD}} \mathrm{F}$ or ${ }_{\mathrm{CBD}} \mathrm{I}$, and $\mathrm{CBD}_{\mathrm{C}} \mathrm{H}$ pulled down GvpG, GvpJ, GvpK, GvpL or GvpM (Figure 1 and Table 2). GvpG monomers and dimers were selected by $\mathrm{CBD}_{\mathrm{B}} \mathrm{F}$, whereas $\mathrm{CBD}_{\mathrm{C}} \mathrm{H}, \mathrm{CBD}$ I and $\mathrm{CBD}_{\mathrm{C}} \mathrm{L}$ selected the dimer of GvpG (and additional multimers in the case of ${ }_{\mathrm{CBD}} \mathrm{I}$ ) (Figure 1). Since ${ }_{\mathrm{CBD}} \mathrm{G}$ bound GvpM, GvpK and GvpJ, these results demonstrated that GvpG is able to interact with all accessory proteins. Similar results were obtained with GvpF, since GvpF was pulled down by ${ }_{C B D} I$, and ${ }_{C B D}$ F pulled down GvpG, $\mathrm{GvpH}$, and GvpJ through GvpM (Figure 1 and Table 2). Overall, the results of these pull-down experiments implied that any accessory Gvp had multiple interaction partners and suggested that these proteins might form a larger complex.

\section{Accessory Gvp Proteins Selected by CBDM}

To investigate whether GvpM was able to select all accessory Gvp at once, Hfx. volcanii transformants were produced carrying ${ }_{\mathrm{CBD}} \mathrm{M}$ and in addition the plasmid $\mathrm{pF}-\mathrm{L}^{\mathrm{ex}}$ expressing $g v p F G H I J K L$ under the strong $P_{f d x}$ promoter control. The interaction partners of ${ }_{C B D} \mathrm{M}$ were selected by pull-down experiments from the lysate of this transformant, and samples were tested by Western analyses using the different antisera (Figure 2). All accessory Gvp were identified, implying that ${ }_{\mathrm{CBD}} \mathrm{M}$ attracted all of them. In each case the respective monomeric Gvp was detected. In the case of GvpG, two 30-34 kDa bands were visible in addition to the expected $10-\mathrm{kDa}$ GvpG protein, and GvpJ and GvpK also formed multimers (Figure 2). The monomer of the ${ }_{\mathrm{CBD}} \mathrm{M}$ bait protein was also detected (Figure 2). Overall, ${ }_{\mathrm{CBD}} \mathrm{M}$ was able to pull down GvpF through GvpL. It is possible that each of these Gvp proteins bound independently to ${ }_{\mathrm{CBD}} \mathrm{M}$, but it is also possible that some or all of them formed a complex that bound to GvpM.

\section{Protein-Protein Interactions Investigated by Split-GFP}

Pairwise interactions of the accessory Gvp proteins were studied in $H f x$. volcanii in vivo using the split-GFP method. Each gvp reading frame was amplified by PCR and inserted in the four vector plasmids to fuse the $n g f p$ - or $c g f p$ reading frame to the $5^{\prime}$ or $3^{\prime}$ terminus of each gvp (Winter et al., 2018). The Nand C-terminal GFP fragments NGFP and CGFP derive from the salt-adapted, green fluorescent protein mGFP2 (Born and Pfeifer, 2019). A fluorescent GFP is only formed when the two fusion partners interact and steric hindrance does not occur. The reading frame of each fusion protein is expressed under the $P_{f d x}$ promoter control to yield similarly large amounts of these proteins. The four N/CGFP fusions were designated ${ }_{N} X$, or ${ }_{C} X$ for the $\mathrm{N}$-terminal fusion, and $\mathrm{X}_{\mathrm{C}}$ or $\mathrm{X}_{\mathrm{N}}$ for the $\mathrm{C}$-terminal fusion with Gvp (with $\mathrm{X}$ = respective accessory Gvp; C = CGFP; $\mathrm{N}=\mathrm{NGFP}$ ). The eight combinations of a protein pair were tested in Hfx. volcanii transformants and the fluorescence was measured in arbitrary light absorbing units per $\mathrm{mm}^{2}$. The highest relative fluorescence (rf-values) calculated for each interaction pair are shown in Supplementary Figure 4, and the original data obtained in $\mathrm{LAU} / \mathrm{mm}^{2}$ are presented in Supplementary Figure 5. A summary of these data is shown in Figure 3.

The highest relative fluorescence of all interactions was observed with the ${ }_{\mathrm{N}} \mathrm{G} / \mathrm{CL}$ transformant ( $\mathrm{rf}$ 77.5) implying a strong interaction of GvpL with GvpG (Figure 3A). All other interaction partners of GvpL yielded rf-values below 20. Rf-values between 10 and 20 were observed for the interaction $\mathrm{F}_{\mathrm{C}} / \mathrm{N}_{\mathrm{L}} \mathrm{L}$, ${ }_{\mathrm{N}} \mathrm{I} / \mathrm{L}_{\mathrm{C}}, \mathrm{M}_{\mathrm{C}} / \mathrm{L}_{\mathrm{N}}, \mathrm{H}_{\mathrm{N}} / \mathrm{L}_{\mathrm{C}}$, and $\mathrm{J}_{\mathrm{C}} / \mathrm{N}_{\mathrm{L}} \mathrm{L}$, and $\mathrm{rf} 7.4$ was determined for $\mathrm{K}_{\mathrm{C}} / \mathrm{N}_{\mathrm{N}} \mathrm{L}$ (Figures 3A,B and Supplementary Figure 5). These results implied that the $32-\mathrm{kDa}$ GvpL interacted with all other accessory Gvp. GvpL is the largest of the accessory Gvp and might act as platform to bind all others. Also, GvpF interacted with several Gvp proteins (GvpL, GvpH, GvpI, and GvpG) (Figure 3B). The $\mathrm{F}_{\mathrm{C}} / \mathrm{L}_{\mathrm{N}}$ transformant ( $\mathrm{rf}$ 16.6) exhibited the highest relative fluorescence, whereas the other three binding partners yielded lower rf-values (rf 5.0-6.3). In the case of GvpF it should be mentioned that the highest fluorescence was always observed when $\mathrm{N}$ - or CGFP was fused to the C-terminus of GvpF, suggesting that a fusion to the $\mathrm{N}$-terminus hinders the assembly of mGFP2. The 23-kDa GvpF is smaller than GvpL, but both proteins exhibit sequence similarities and a similar 3D-structure when modeled using the crystal structure of the cyanobacterial GvpF as template (Xu et al., 2014; Winter et al., 2018).

The second highest fluorescence ( $\mathrm{rf} 20$ ) of all combinations was observed for the $\mathrm{H}_{\mathrm{C}} / \mathrm{N}_{\mathrm{I}}$ transformant (Figure 3), implying that $\mathrm{GvpH}$ and GvpI attract each other. Both proteins also interacted with GvpF and GvpL (rf 6.3). Two partner proteins 

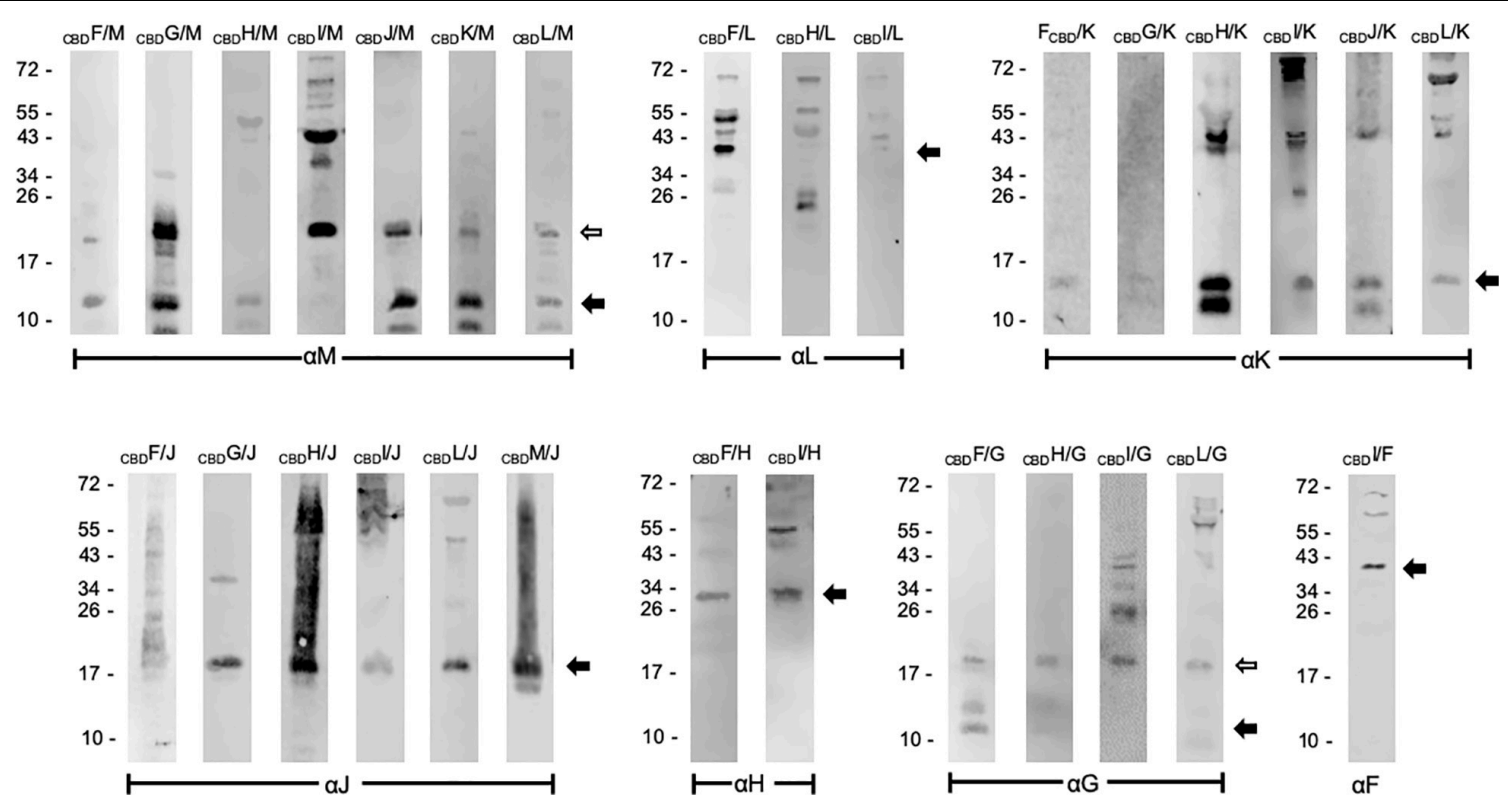

FIGURE 1 | Western analyses of the pull-down assays using ${ }_{\mathrm{CBD}} \mathrm{X}$. The bait $\mathrm{CBD}_{\mathrm{X}} \mathrm{X}$ and the prey protein $\mathrm{Y}(\mathrm{X}, \mathrm{Y}=$ any $\mathrm{GvpF}$ through GvpM protein) were synthesized in the same Hfx. volcanii cell. Both are marked on the top of the blots. Only the elution fraction of the cellulose matrix is shown. In each case, $15 \mu \mathrm{L}$ of the elution fraction was separated by SDS-PAGE, the proteins transferred to a PVDF membrane and incubated with the respective antiserum indicated underneath ( $\alpha$ F through $\alpha M)$. The putative interaction partners were visualized with the fluorophore-labeled secondary antibody IRDye $800 \mathrm{CW}$ (Licor). The blots are inverted to black-white and arranged according to the respective antiserum used. Arrows mark the expected Gvp monomer and dimer. Numbers on the left are size markers in kDa.

TABLE 2 | Summary of the pull-down experiments using CBD Gvp.

\begin{tabular}{|c|c|c|c|c|c|c|c|c|}
\hline & GvpF & GvpG & GvpH & Gvpl & GvpJ & GvpK & GvpL & GvpM \\
\hline $\mathrm{CBD}^{\mathrm{F}}$ & & GvpG & GvpH & + & (GvpJ) (aggregate) & GvpK (weak) & GvpL & GvpM \\
\hline $\mathrm{CBD} G$ & + & & + & + & (GvpJ) (monomer+dimer) & GvpK (weak) & + & GvpM \\
\hline $\mathrm{CBD} H$ & + & GvpG (dimer) & & + & (GvpJ) (aggregate) & GvpK & (GvpL) & GvpM (monomer) \\
\hline $\mathrm{CBD}$ & GvpF & GvpG (dimer + multimer) & GvpH & + & (GvpJ) (monomer+ aggregate) & $\begin{array}{l}\text { GvpK (Monomer+ } \\
\text { multimer) }\end{array}$ & (GvpL) & GvpM (dimer + multimer) \\
\hline CBDJ & + & + & + & + & & GvpK & + & GvpM \\
\hline $\mathrm{CBD} K$ & + & + & + & + & + & & + & GvpM \\
\hline CBDL & + & GvpG (dimer) & $(-)$ & $(-)$ & GvpJ (monomer) & GvpK & & GvpM (monomer) \\
\hline $\mathrm{CBD} M$ & + & + & + & + & GvpJ (aggregate) & + & + & \\
\hline
\end{tabular}

GvpX interaction detected.

+ interaction was shown in another combination.

- no interaction identified.

() interaction not clear.

were identified for GvpG (GvpL and GvpF), and GvpL appeared to be the only interaction partner of the three proteins GvpJ, GvpK and GvpM (Figure 3B). Overall, these results obtained by these split-GFP analyses demonstrated that all accessory Gvp proteins had at least one other Gvp protein as interaction partner. Since GvpL bound all of them it is possible that they form a larger complex. Compared to the results obtained by affinity chromatography using ${ }_{\mathrm{CBD}} \mathrm{Gvp}$, less interactions were observed with split-GFP, especially for the two hydrophobic proteins GvpJ $(12 \mathrm{kDa})$ and $\mathrm{GvpM}(9.2 \mathrm{kDa})$, and for GvpK $(12.6 \mathrm{kDa})$.

\section{Interaction Partner(s) of GvpA}

To uncover interactions between the major structural gas vesicle protein GvpA and these accessory Gvp, each combination of
A/X (X = GvpF through GvpM) was investigated by split-GFP. GvpA was fused at the $\mathrm{N}$ - or C-terminus to $\mathrm{N}$ - or CGFP and tested pairwise with the respective N/CGFP fusion variants of GvpF through GvpM. Eight different combinations were investigated for each pair, and the highest rf-values calculated in each case are shown in Figure 4A. The original data obtained in these experiments is presented in Supplementary Figure 6. The highest relative fluorescence was obtained for the $A_{C} / F_{N}$ transformant ( $\mathrm{rf} 20$ ), whereas all other transformants yielded $\mathrm{rf}-$ values $<1$, suggesting very weak contacts between GvpA and the other Gvp proteins (Figure 4A). Except of ${ }_{N} A / L_{C}$, the highest fluorescence of a protein pair was always observed when $\mathrm{N}$ or CGFP was fused to the C-terminus of GvpA. These results implied that GvpF is the only interaction partner of GvpA, 


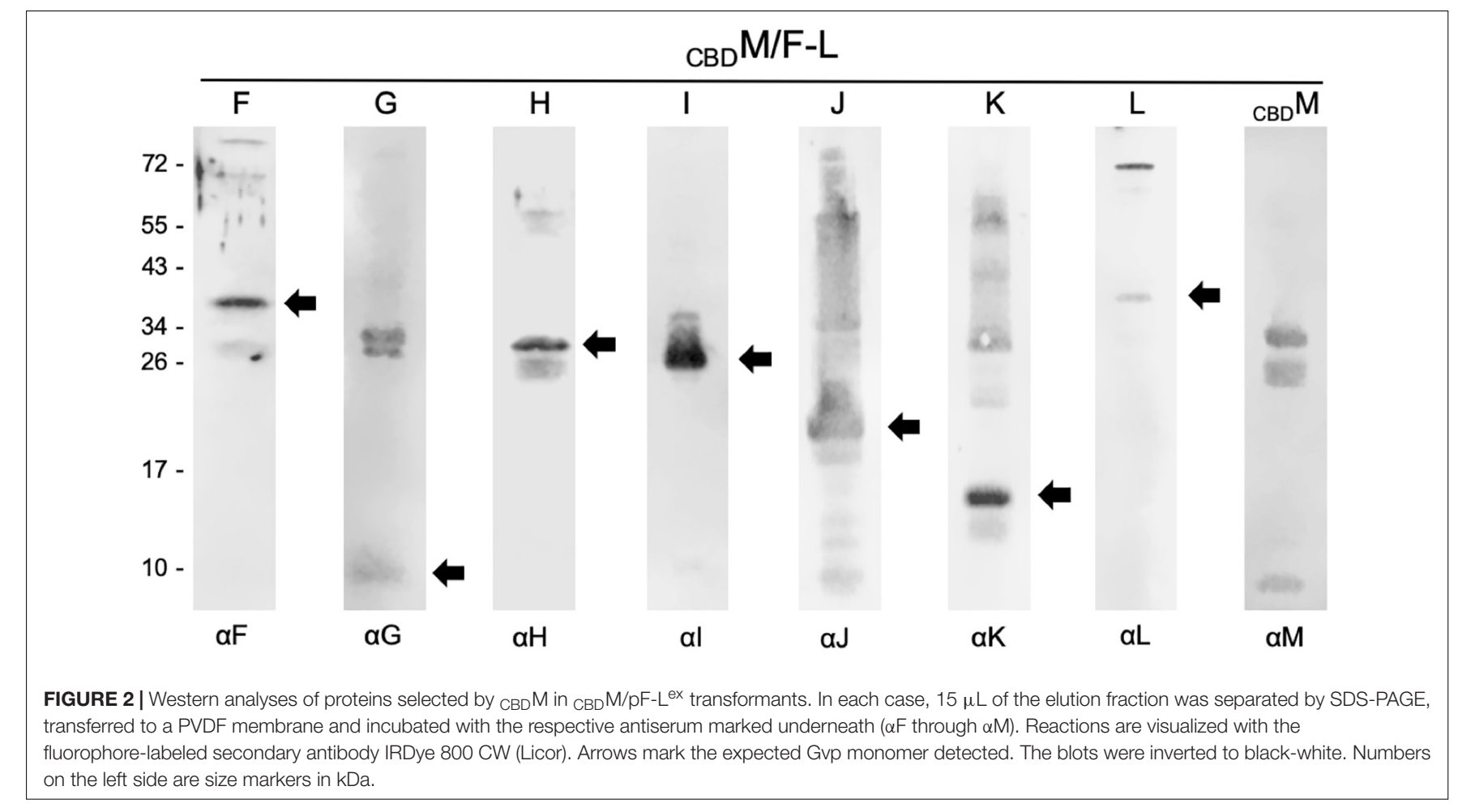

\section{A}

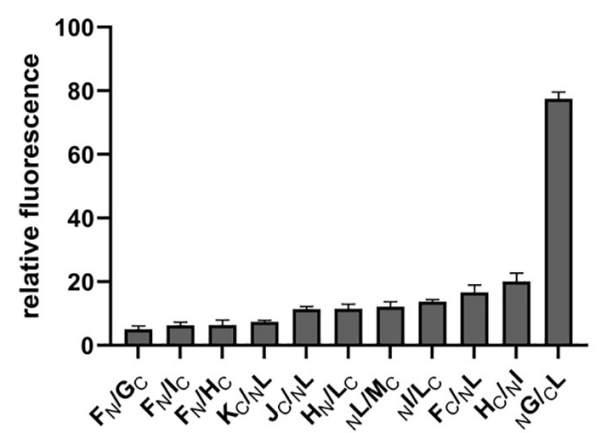

B

\begin{tabular}{|c|c|c|c|c|c|c|c|}
\hline GvpF & $\begin{array}{c}\text { GvpL } \\
(16.62)\end{array}$ & $\begin{array}{c}\text { GvpH } \\
(6.35)\end{array}$ & $\begin{array}{c}\text { Gvpl } \\
(6.30)\end{array}$ & $\begin{array}{c}\text { GvpG } \\
(5.07)\end{array}$ & $\begin{array}{c}\text { GvpK } \\
(1.73)\end{array}$ & $\begin{array}{c}\text { GvpM } \\
(1.58)\end{array}$ & $\begin{array}{c}\text { GvpJ } \\
(0.75)\end{array}$ \\
\hline GvpG & $\begin{array}{c}\text { GvpL } \\
(77.45)\end{array}$ & $\begin{array}{c}\text { GvpF } \\
(5.07)\end{array}$ & $\begin{array}{c}\text { Gvpl } \\
(2.18)\end{array}$ & $\begin{array}{c}\text { GvpK } \\
(1.90)\end{array}$ & $\begin{array}{c}\text { GvpH } \\
(0.58)\end{array}$ & $\begin{array}{c}\text { GvpJ } \\
(0.54)\end{array}$ & $\begin{array}{c}\text { GvpM } \\
(0.34)\end{array}$ \\
\hline GvpH & $\begin{array}{c}\text { Gvpl } \\
(20.04)\end{array}$ & $\begin{array}{c}\text { GvpL } \\
(11.44)\end{array}$ & $\begin{array}{c}\text { GvpF } \\
(6.35)\end{array}$ & $\begin{array}{c}\text { GvpK } \\
(0.92)\end{array}$ & $\begin{array}{c}\text { GvpG } \\
(0.58)\end{array}$ & $\begin{array}{c}\text { GvpJ } \\
(0.51)\end{array}$ & $\begin{array}{c}\text { GvpM } \\
(0)\end{array}$ \\
\hline Gvpl & $\begin{array}{c}\text { GvpH } \\
(20.04)\end{array}$ & $\begin{array}{c}\text { GvpL } \\
(13.70)\end{array}$ & $\begin{array}{c}\text { GvpF } \\
(6.30)\end{array}$ & $\begin{array}{c}\text { GvpK } \\
(3.08)\end{array}$ & $\begin{array}{c}\text { GvpG } \\
(2.18)\end{array}$ & $\begin{array}{c}\text { GvpM } \\
(1.97)\end{array}$ & $\begin{array}{c}\text { GvpJ } \\
(1.16)\end{array}$ \\
\hline GvpJ & $\begin{array}{c}\text { GvpL } \\
(11.35)\end{array}$ & $\begin{array}{c}\text { Gvpl } \\
(1.16)\end{array}$ & $\begin{array}{c}\text { GvpK } \\
(1.13)\end{array}$ & $\begin{array}{c}\text { GvpF } \\
(0.75)\end{array}$ & $\begin{array}{c}\text { GvpG } \\
(0.54)\end{array}$ & $\begin{array}{c}\text { GvpH } \\
(0.51)\end{array}$ & $\begin{array}{c}\text { GvpM } \\
(0.51)\end{array}$ \\
\hline GvpK & $\begin{array}{c}\text { GvpL } \\
(7.39)\end{array}$ & $\begin{array}{c}\text { Gvpl } \\
(3.08)\end{array}$ & $\begin{array}{c}\text { GvpG } \\
(1.90)\end{array}$ & $\begin{array}{c}\text { GvpF } \\
(1.73)\end{array}$ & $\begin{array}{c}\text { GvpM } \\
(1.22)\end{array}$ & $\begin{array}{c}\text { GvpJ } \\
(1.13)\end{array}$ & $\begin{array}{c}\text { GvpH } \\
(0.92)\end{array}$ \\
\hline GvpL & $\begin{array}{c}\text { GvpG } \\
(77.45)\end{array}$ & $\begin{array}{c}\text { GvpF } \\
(16.62)\end{array}$ & $\begin{array}{c}\text { Gvpl } \\
(13.70)\end{array}$ & $\begin{array}{c}\text { GvpM } \\
(12.13)\end{array}$ & $\begin{array}{c}\text { GvpH } \\
(11.44)\end{array}$ & $\begin{array}{c}\text { GvpJ } \\
(11.35)\end{array}$ & $\begin{array}{c}\text { GvpK } \\
(7.39)\end{array}$ \\
\hline GvpM & $\begin{array}{l}\text { GvpL } \\
(12.13)\end{array}$ & $\begin{array}{c}\text { Gvpl } \\
(1.97)\end{array}$ & $\begin{array}{c}\text { GvpF } \\
(1.58)\end{array}$ & $\begin{array}{c}\text { GvpK } \\
(1.22)\end{array}$ & $\begin{array}{c}\text { GvpJ } \\
(0.51)\end{array}$ & $\begin{array}{c}\text { GvpG } \\
(0.34)\end{array}$ & $\begin{array}{c}\text { GvpH } \\
(0)\end{array}$ \\
\hline
\end{tabular}

Dark red: >30; red: 20 - 30; light red: 10 - 19; yellow: 5 - 9; light blue: 1 - 4; blue: <1

FIGURE 3 | Interactions of the accessory Gvp determined by split-GFP. (A) Highest relative fluorescence (rf-values) determined for the protein-protein interactions calculated as described in the methods section. All experiments were performed with two biological and three technical replicates. (B) Summary of the different protein-protein interactions determined by split-GFP. The Gvp proteins tested are shown in the gray box on the left and their interaction partners are arranged according to the highest rf-value determined (given underneath). A fluorescence exceeding if $>5$ was regarded as clear interaction. Rf-values $<$ if 4 are regarded as weak or no interaction.

and that the N-terminal region of GvpA might be involved in the interaction.

To define the interaction site of GvpF in GvpA more precisely, five GvpA fragments harboring different structural features (according to the model obtained by Strunk et al. (2011)) were studied by split-GFP. Fragment A1-22 encompasses the first 22 amino acids of GvpA including $\alpha$-helix $1(\alpha 1)$, fragment A1-34 contains in addition $\beta$-sheet $1(\alpha 1-\beta 1)$, and A1-43 the $\alpha 1-\beta 1$ $\beta 2$ elements of GvpA (Figure 4C). Fragment A20-47 contains $\beta 1-\beta 2$, and A44-76 the $\alpha$-helix 2 up to the C-terminus of GvpA $(\alpha 2)$ (Figure 4C). Each of these GvpA fragments was fused at the $\mathrm{N}$ - or C-terminus to $\mathrm{N}$ - or CGFP and tested with the respective N/CGFP fusion of GvpF. Transformant $\mathrm{F}_{\mathrm{N}} / \mathrm{A} 1-22_{\mathrm{C}}$ yielded the highest fluorescence ( $\mathrm{rf} 41$ ), i.e., more than twice 


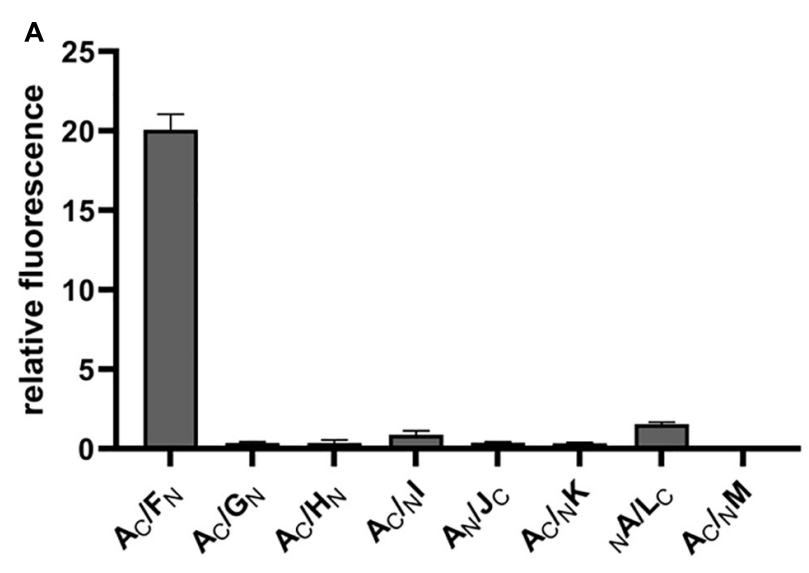

B

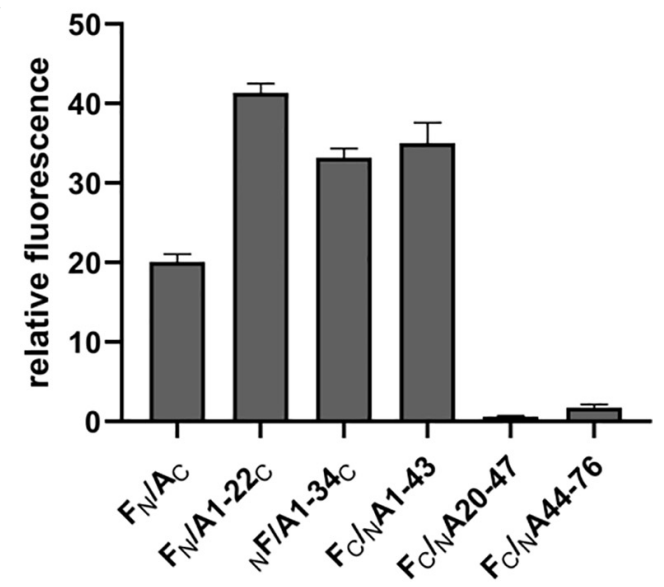

C

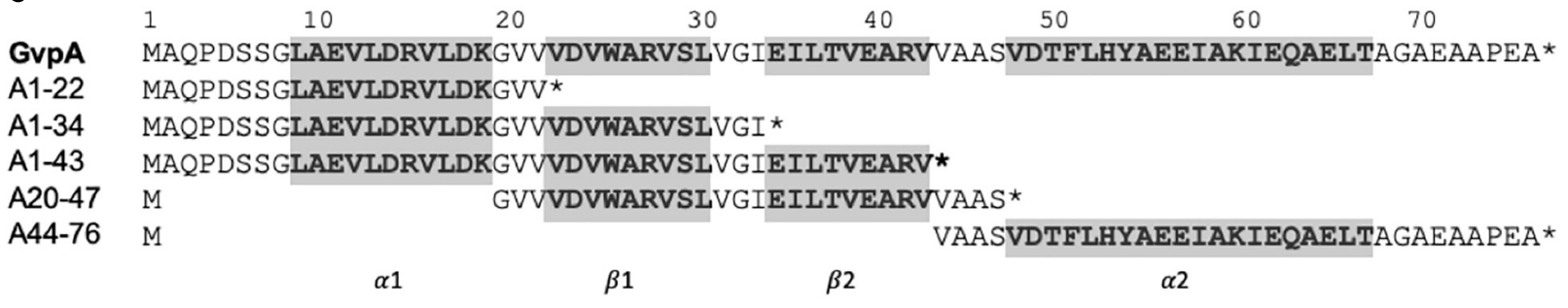

FIGURE 4 | Split-GFP interaction studies with GvpA/GvpX. Only the highest relative fluorescence determined for each combination is given. Two biological and three technical replicates were performed in each case. (A) Interaction study of GvpA with the eight accessory proteins GvpF through GvpM. (B) Interaction of five different GvpA fragments with GvpF. (C) Sequence of the five GvpA fragments in relation to the aa sequence of GvpA shown on top. Numbers above the sequence depict the aa positions in GvpA. The helices $\alpha 1$ and $\alpha 2$ and the $\beta$-sheets $\beta 1$ and $\beta 2$ are in bold and marked on the bottom and also shaded in gray.

as high as obtained for the interaction of GvpF with the entire GvpA (rf 20) (Figure 4B). Smaller protein fragments offer less steric hindrance supporting the interaction (Ghosh et al., 2000; Winter et al., 2018). An increased fluorescence was also found for the transformants harboring F/A1-34 and F/A1-43 (rf 33 35 ), whereas a very low relative fluorescence ( $\mathrm{rf}<1$ ) was obtained for the transformants harboring F/A20-47 or F/A4476. These results implied that the C-terminal portion of GvpA is not involved, and that the $\mathrm{N}$-terminal portion contains the interaction site of GvpF.

To further confine the interaction site of GvpF in GvpA, various substitution variants of GvpA were tested by split-GFP. Many of these point mutations in GvpA are known to influence the formation of gas vesicles in $\Delta \mathrm{A}+\mathrm{A}_{\text {mut }}$ transformants (Strunk et al., 2011; Knitsch et al., 2017). These transformants carry two vector plasmids, the $\Delta \mathrm{A}$ construct (contains except $g v p A$ all $g v p$ genes of the $\mathrm{p}$-vac region) and construct $\mathrm{A}$ ( $g v p A$ or mutant $g v p A$ expressed in pMDS20 under the control of the native $P_{A}$ promoter). The different GvpA variants were investigated by split-GFP analysis for their potential to interact with GvpF in Hfx. volcanii. The $\mathrm{F}_{\mathrm{N}}$ fusion protein was used as interaction partner in all these cases (Figure 5A). The strongest reductions in relative fluorescence $(\mathrm{rf}<6$ ) compared to GvpA wild type ( $\mathrm{rf}$ 15-18) were observed for the GvpA substitutions G20D, G20A, D24A, D24Y, R28A, R28D, or E40A, but also R15A, K19D,
$\mathrm{A} 27 \mathrm{E}$, or $\mathrm{G} 33 \mathrm{~V}$ resulted in a low relative fluorescence of the F/A mut transformants (Figure 5A and Supplementary Figure 6). Especially the charged aa in $\beta 1$ and $\beta 2$ (D24, R28, E40) and G20 of GvpA had a strong influence on the interaction with GvpF (Figure 5). All these aa are located in the $\mathrm{N}$-terminal half of GvpA, whereas any of the single substitutions in the C-terminal half had no effect on the interaction with GvpF, supporting the results described above. It is likely that these aa of GvpA are involved in the GvpF/GvpA interaction. In respect to the gas vesicle phenotype of the $\Delta \mathrm{A}+\mathrm{A}_{\text {mut }}$ transformants, most of these mutations result in a $\mathrm{Vac}^{-}$phenotype, except for D24A (cylindrical) and R28A (mini gas vesicles) (Knitsch et al., 2017; Figure 5B). It is possible that the $\mathrm{Vac}^{-}$phenotype is caused by the lack of an interaction between GvpF and GvpA, rather than (or in addition to) an influence of the mutation on the GvpA/GvpA contact in the gas vesicle wall.

\section{DISCUSSION}

Gas-vesicle assembly involves twelve Gvp proteins, two of which, GvpA and GvpC, form the gas vesicle wall. A third protein, GvpN, is required for the enlargement of the structure, and the function of GvpO is not yet known (Pfeifer, 2012). The accessory proteins GvpF through GvpM are encoded by an 


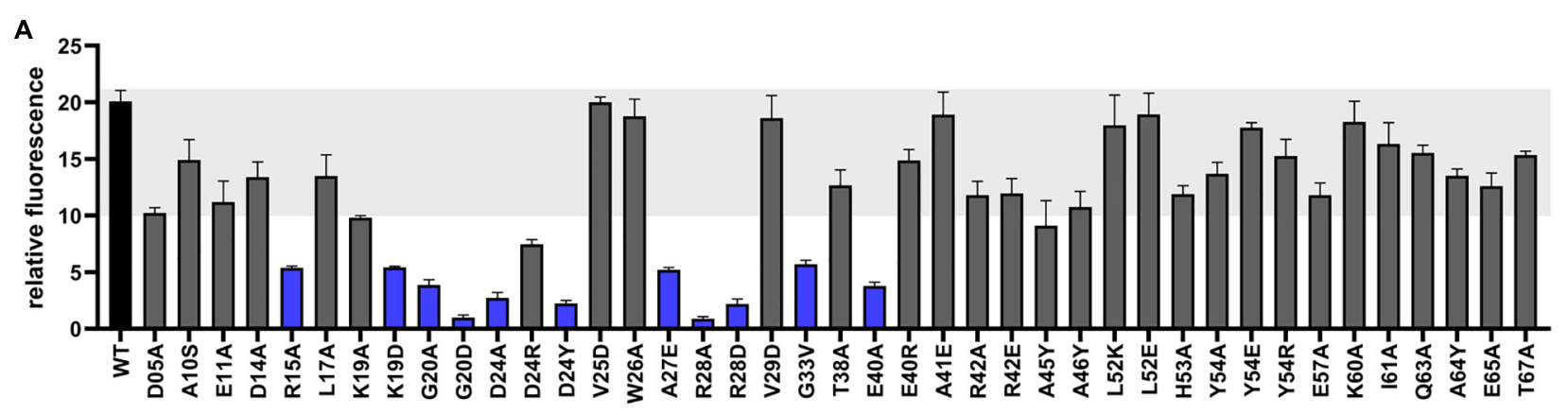

B

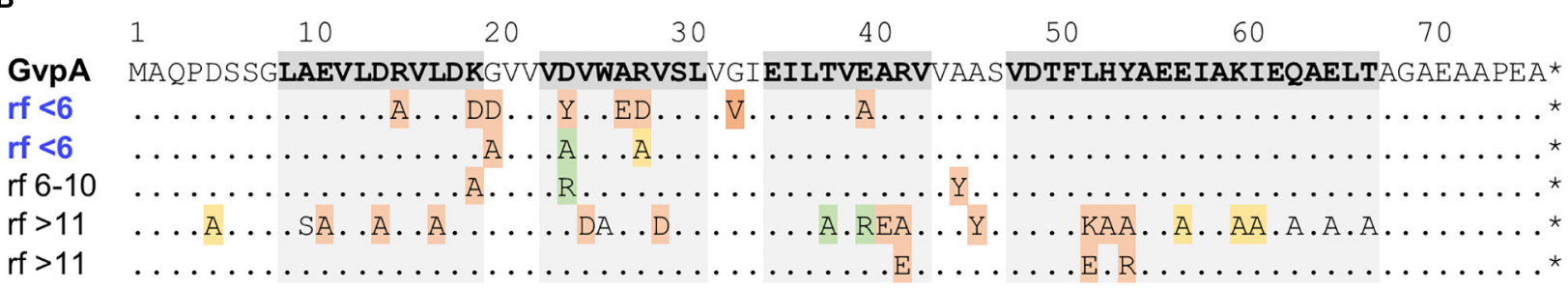

FIGURE 5 | Split-GFP studies of GvpF and variants of GvpA mut. (A) Rf-values of the GvpF/GvpA (WT) and the various F/Amut transformants. The single substitutions in GvpA are indicated below. F/Amut transformants with relative fluorescence $<6$ are labeled in blue. The fluorescence was determined in $L A U / \mathrm{mm}^{2}$, and the relative fluorescence in relation to the fluorescence of $H f x$. volcanii wild type calculated. Two biological and three technical replicates were performed in each case. (B). Sequence of GvpA and summary of the if-values of the various GvpA mutants. The sequence of GvpA is presented on top and the structural features $\alpha 1-\beta 1-\beta 2-\alpha 2$ shaded in grey. The substitutions in GvpA are summarized underneath; each GvpA contains only a single substitution. Rf $<6$ is regarded as weak interaction, whereas if $>11$ is similar to GvpA wild type. The Vac phenotype of the respective $\Delta A+A_{m u t}$ transformants is indicated by color: red, Vac negative; green, cylinder shaped; yellow, mini gas vesicles; without color, wild type gas vesicles.

operon and produced in minor amounts in early exponential growth. All eight accessory Gvp were investigated pairwise in respect to their interaction(s) and also with the major gas vesicle structural protein, GvpA.

\section{Pull-Down Experiments Imply Complex Formation of the Accessory Gvp}

Earlier pull-down experiments with His Gvp proteins indicated non-specific binding of other histidine-rich proteins (such as PitA) to the Ni-NTA matrix, and also non-specific reactions of the Gvp antisera in Western analyses (Tavlaridou et al., 2014, and unpublished observations). In contrast, pull-down assays with $\mathrm{CBD}_{\mathrm{Bvp}}$ on a cellulose matrix yielded a high specificity in the selection. In most cases, single protein bands were detected in the elution fraction, but also multimers were observed, especially with GvpJ, GvpK, and GvpM. None of the Gvp proteins bound to cellulose when the CBD tag was lacking, and the putative binding partner(s) of a given Gvp protein were selected in the respective $\mathrm{CBD} X / \mathrm{Y} H f x$. volcanii transformants. Earlier studies with His $\mathrm{M}$ implied an interaction of GvpM with GvpH, GvpJ, and GvpL, but not with GvpG (Tavlaridou et al., 2014). Testing the selection of these Gvp with ${ }_{\mathrm{CBD}} \mathrm{M}$ verified these interactions, but GvpM also interacted with GvpG. A reason for this result could be that the pull-down experiments based on CBD-tagged proteins were performed in vivo with transformants synthesizing both bait and prey, whereas the earlier analyses with ${ }_{\text {His }}$ Gvp were performed in vitro with proteins isolated from $E$. coli and refolded in high salt solutions. Only the prey protein was synthesized in Hfx. volcanii (Tavlaridou et al., 2014). The larger range of interactions observed with $\mathrm{CBDX}$ compared to $\mathrm{His} \mathrm{X}$ might be due to the correct folding of bait and prey under in vivo conditions. It should be noted that GvpJ and GvpM, but also GvpK oligomerized in the presence of $\mathrm{CBD}$, whereas other ${ }_{\mathrm{CBD}} \mathrm{X}$ selected only monomers and/or dimers of these accessory Gvp. The very positively charged GvpI ( $\mathrm{pK}$ 10.75) might be able to bind and connect the negatively charged Gvp ( $\mathrm{pK} 4-5$ ). GvpI contains 23 lysine and arginine residues in the N-terminal 53 aa, and the involvement of these aa in the oligomerization of the other proteins and also in the assembly of gas vesicles should be analyzed in further detail.

The results obtained by the pairwise ${ }_{\mathrm{CBD}} \mathrm{X} / \mathrm{Y}$ pull-down experiments suggested that all accessory Gvp proteins interact. In almost all cases, the prey proteins were detected by Western analyses. A quantitation of the binding efficiency is difficult, since different antisera were used. A quantitation of the interaction was easier using the split-GFP method and measuring the fluorescence of the cells in vivo. The interaction network derived from the pull-down studies suggested that all Gvp proteins attract each other and possibly form a complex. Studies with ${ }_{\mathrm{CBD}} \mathrm{M}+\mathrm{pF}$ $\mathrm{L}^{\mathrm{ex}}$ transformants demonstrated that GvpM indeed selected all the Gvp proteins at once (Figure 2). It is possible that any of these proteins interacted solely with GvpM, but it is likely that they bound as a complex to the bait. GvpM is required in early steps of gas-vesicle assembly as deduced from studies with $\Delta \mathrm{M}+\mathrm{M}_{\text {mut }}$ transformants harboring construct $\Delta \mathrm{M}$ complemented by GvpM variants with single aa substitutions (Tavlaridou et al., 2014). Only 


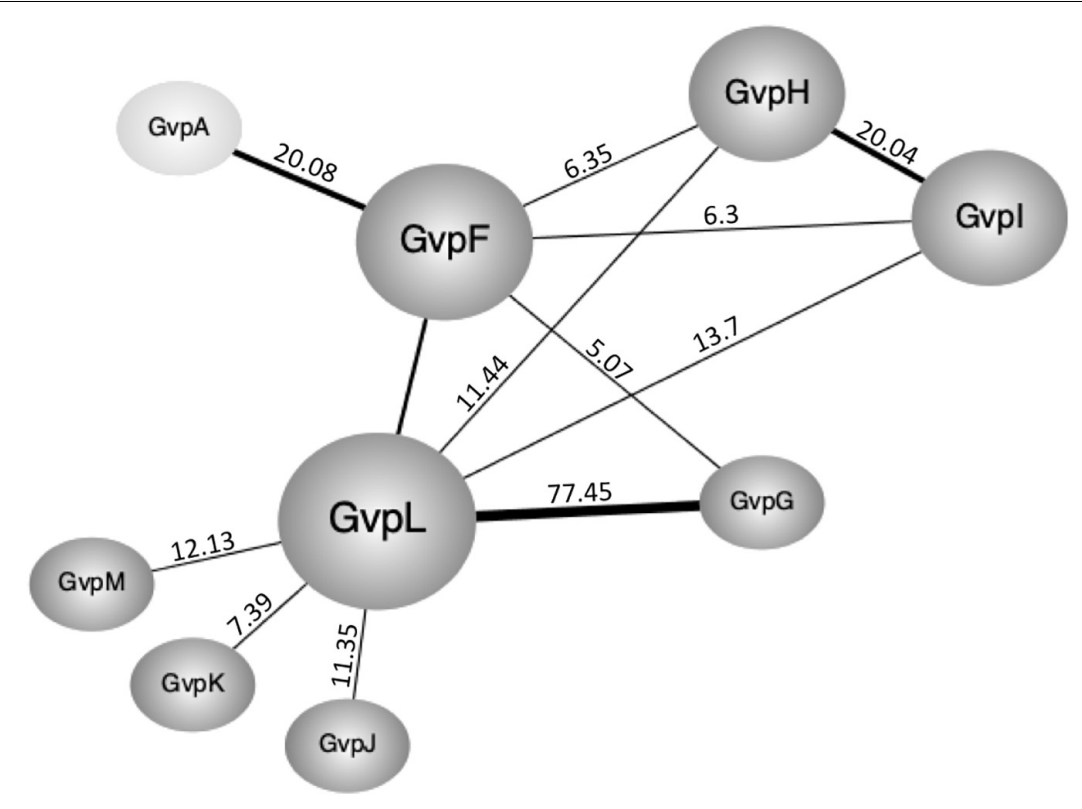

FIGURE 6 | Interaction network of the accessory Gvp and GvpA as obtained by split-GFP. Only clear interactions (If > 5) are incorporated. The respective rf-values are given at the connecting lines. Rf-values $>20$ are indicated by thicker lines.

$\mathrm{Vac}^{+}$or $\mathrm{Vac}^{-}$transformants were obtained, whereas variants in gas vesicle shape (as found with many $\Delta \mathrm{A}+\mathrm{A}_{\text {mut }}$ transformants) were not observed, implying that GvpM is involved in an early step in gas-vesicle assembly.

\section{Gvp Interaction Network Deduced by Split-GFP}

The split-GFP method is easy to apply and the interactions can be semi-quantified. Each protein pair under investigation requires the analysis of eight combinations to exclude a possible steric hindrance in the assembly of GFP (Winter et al., 2018). Not all of the transformants tested were significantly fluorescent. The calculated relative fluorescence (rf) varied from $\mathrm{rf}$-values $<1$, regarded as no protein-protein interaction, over $\mathrm{rf} 1-5$ regarded as weak, to $\mathrm{rf}>5$ regarded as clear interaction. The data was used to establish a network of the accessory Gvp including all interactions exceeding rf 5 (Figure 6).

The highest number of protein contacts was observed for GvpL that was shown to interact with all other accessory Gvp. The highest rf-value of all combinations tested was found with GvpL/GvpG ( $r f$ 77.45). The $10-\mathrm{kDa}$ GvpG is relatively small, similar to GvpJ, GvpK, and GvpM (9.2-12.6 kDa). The latter three proteins yielded GvpL as sole interaction partner, whereas GvpG also contacted GvpF. It is possible that the hydrophobic nature of GvpM and GvpJ and their tendency to aggregate prevented the assembly of sufficient fluorescent GFP in some cases. GvpL ( $32 \mathrm{kDa}$ ) and $\mathrm{GvpF}(23 \mathrm{kDa})$ are structurally related as determined by homology modeling using a crystal structure of $\mathrm{GvpF}$ derived from the cyanobacterium Microcystis aeruginosa as template (Xu et al., 2014; Winter et al., 2018). Since GvpL attracted all other accessory Gvp, this protein might play a central role in the formation of a protein complex. However, it is not known so far whether the binding of the other Gvp occurs at the same time or sequentially.

The interaction partners of GvpF were GvpG, GvpH, GvpI, and GvpL as deduced from the split-GFP analyses (Figures 3, 6). GvpH (19.8 kDa) and GvpI (15.8 kDa) are interesting, since both are non-essential for gas vesicle formation and appear to interact with each other; a relatively high fluorescence (rf 20) was observed for GvpH/GvpI. Both proteins interacted also with GvpL and GvpF. The binding to GvpL resulted in higher rfvalues (rf 11.4, GvpH and rf 13.7, GvpI) compared to the rf-values obtained with GvpF (rf 6.3 in both cases) suggesting that the preferred interaction partner of GvpH and GvpI is GvpL. It is possible that GvpH and GvpI form a heterodimer that binds only temporary to the putative complex. GvpH influences the stability of the gas vesicles, whereas a lack of the positively charged GvpI results in extremely long gas vesicles (Offner et al., 2000). Previous studies also suggest that the presence of $\mathrm{GvpH}$ prevents the aggregation of GvpM (Tavlaridou et al., 2014). As shown by the pull-down experiments performed in this report, $\mathrm{CBD} H$ selected GvpM as monomer and not as dimer, whereas all other accessory Gvp selected GvpM additionally as dimer (Figure 1). In contrast, GvpI induced the oligomerization of GvpJ, GvpK, and GvpM (Figure 1). To uncover the exact functions of GvpH and GvpI during gas vesicle formation, both proteins should be investigated in further detail.

Overall, the interaction studies by split-GFP yielded less interactions compared to the pull-down experiments, especially for the hydrophobic GvpJ and GvpM, but also for GvpK. These three proteins often form multimers as observed when investigated by SDS-PAGE. Studies on self-interactions of the Gvp proteins yielded only weak interactions for $\mathrm{F} / \mathrm{F}$ ( $\mathrm{rf} 1.5$ ), or $\mathrm{G} / \mathrm{G}$ ( $(\mathrm{ff} 3.5$ ), whereas $\mathrm{J} / \mathrm{J}, \mathrm{K} / \mathrm{K}$ or $\mathrm{M} / \mathrm{M}$ transformants were not fluorescent (Supplementary Figure 7). The formation of 


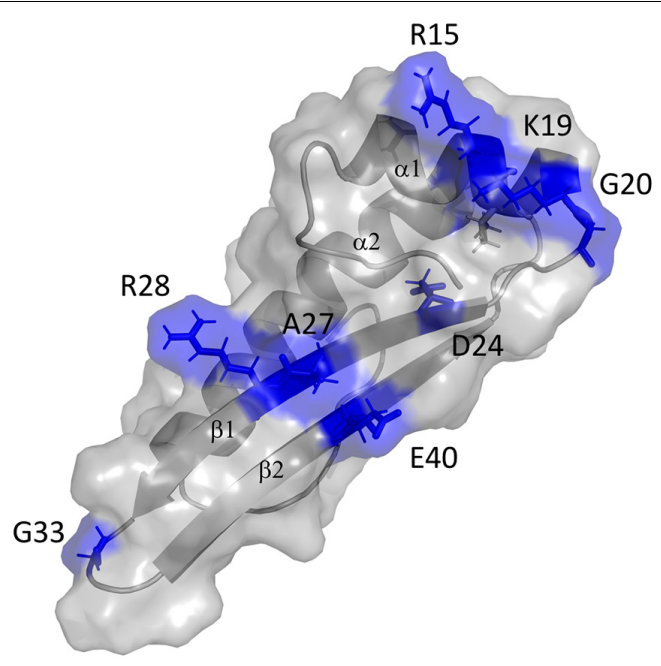

FIGURE 7 | 3D-model of GvpA and putative interaction site of GvpF. The GvpA in silico model is according to Strunk et al. (2011). The secondary structural features $\alpha 1, \beta 1, \beta 2$, and $\alpha 2$ are labeled. The amino acids marked and colored in blue are positions where a substitution resulted in a low relative fluorescence of the F/Amut transformants.

additional multimers might prevent the formation of fluorescent GFP. These results implied that self-interaction of aggregating proteins is difficult to detect by split-GFP.

\section{GvpF Is the Only Interaction Partner of GvpA}

The analysis of the major gas vesicle structural protein, GvpA, by split-GFP uncovered GvpF as sole binding partner. This result implied that a GvpA/GvpF complex is formed, but since GvpF also attracts GvpG, GvpH, GvpI, and via GvpL all other accessory Gvp, it is also possible that a larger complex of the accessory Gvp binds GvpA via GvpF. The latter possibility is more likely, since the amount of GvpF is much smaller than the amount of the major gas vesicle protein GvpA. GvpF is only produced in early growth stages (together with GvpG through GvpM), and not in parallel to the massive production of GvpA later in growth. The $P_{A}$ promoter for the transcription of $g v p A$ is 10 -fold induced by GvpE, whereas the $P_{F}$ promoter for the transcription $g v p F G H I J K L M$ is less active and not activated by GvpE as determined using GFP as reporter (Born and Pfeifer, 2019). Thus, the GvpF/GvpA binding cannot occur on a 1:1 basis throughout growth, and should happen in early stages of gas vesicle formation.

The contact site of GvpF in GvpA was confined to the first 40 aa of GvpA, since substitutions in the second half of this 76-aa protein had no influence on the GvpA/GvpF interaction. Several single substitutions of amino acids in the N-terminal half of GvpA influenced the GvpA/GvpF interaction, and all these positions are also important for gas vesicle formation (Knitsch et al., 2017). These aa are located in $\alpha 1, \beta 1$ and $\beta 2$ of GvpA, and the loop regions in between. Except for D24, the charged aa R15, K19, R28, E40 are located on the surface of GvpA (Figure 7; Strunk et al.,
2011). These aa are thought to form salt bridges to adjacent GvpA molecules in the gas vesicle wall (Sivertsen et al., 2010; Knitsch et al., 2017), but as shown here they also mediate the GvpA/GvpF contact (when GvpF is available). It is possible that GvpF contacts GvpA prior to the incorporation of GvpA in the gas vesicle wall, to keep this strongly hydrophobic protein in solution (especially by shielding $\beta 1-\beta 2$ ) and prevent an undesirable self-aggregation. It is likely that the accessory proteins including GvpF initiate gas vesicle formation by forming a nucleation complex that binds GvpA via GvpF and forces GvpA to start aggregating into the ribs of the gas vesicle wall; this hypothesis has been raised already in Shukla and DasSarma (2004).

\section{CONCLUSION}

A complex (or complexes) of the accessory Gvp proteins might initiate the formation of this gas-filled structure. The aggregation of GvpA to form the ribs of the gas vesicle wall most likely starts at the tips of the two conical end caps of each gas vesicle (Waaland and Branton, 1969), and the small bicones formed are enlarged by further addition of GvpA, and of GvpC at the exterior side. A larger protein complex is required at the tip that binds GvpA to initiate the formation of the gas vesicle wall. The hydrophobic interior surface of ribs formed by GvpA needs to be shielded, especially when the diameter of the conical structure is still small. A complex of the accessory Gvp in both tips could protect and ensure that the ribs become distant enough to expose the hydrophobic surface of GvpA at the interior side and form a hollow structure that rapidly fills with gas. The analysis of the cyanobacterial GvpF by immunogold labeling-based tomography suggests that GvpF is localized at the gas-facing surface of the gas vesicle wall ( $\mathrm{Xu}$ et al., 2014), supporting this hypothesis. The accessory Gvp are presumably not only required in the tip, but also at the transition of the conical caps into the cylinder structure. In addition, helper proteins might be required at the site where the incorporation of GvpA occurs to enlarge the gas vesicle wall. Presumably this site is located in the center of the gas vesicle, and GvpN might be involved here. All these steps in gas-vesicle assembly are not yet understood, but the accessory Gvp proteins and their complex(es) certainly take part in these processes. Further studies will aim to identify the complex(es) formed by the accessory proteins and determine the location in the gas vesicles structure.

\section{DATA AVAILABILITY STATEMENT}

The original contributions presented in the study are included in the article/Supplementary Material, further inquiries can be directed to the corresponding author.

\section{AUTHOR CONTRIBUTIONS}

All authors planned the study, discussed the results, wrote the manuscript, and approved the final manuscript. KV and $\mathrm{AJ}$ performed the analysis. 


\section{FUNDING}

This work was financially supported by the German Research Foundation, DFG (PF 165/15-1). We also acknowledged support by the German Research Foundation and the Open Access Publishing Fund of Technical University Darmstadt.

\section{ACKNOWLEDGMENTS}

We thank Jerry Eichler (Ben-Gurion University, Israel) providing the vector encoding the cellulose binding domain, CBD.

\section{REFERENCES}

Belenky, M., Meyers, R., and Herzfeld, J. (2004). Subunit structure of gas vesicles: a MALDI-TOF mass spectrometry study. Biophys. J. 86, 499-505. doi: 10.1016/ S0006-3495(04)74128-4

Born, J., and Pfeifer, F. (2019). Improved GFP variants to study gene expression in haloarchaea. Front. Microbiol. 10:1200. doi: 10.3389/fmicb.2019.01200

Chu, L. J., Chen, M. C., Setter, J., Tsai, Y. S., Yang, H., Fang, X., et al. (2011). New structural proteins of Halobacterium salinarum gas vesicle revealed by comparative proteomics analysis. J. Proteome Res. 10, 1170-1178. doi: 10.1021/ pr1009383

Englert, C., Krüger, K., Offner, S., and Pfeifer, F. (1992). Three different but related gene clusters encoding gas vesicles in halophilic archaea. J. Mol. Biol. 227, 586-592. doi: 10.1016/0022-2836(92)90914-6

Englert, C., and Pfeifer, F. (1993). Analysis of gas vesicle gene expression in Haloferax mediterranei reveals that GvpA and GvpC are both gas vesicle structural proteins. J. Biol. Chem. 268, 9329-9336.

Fine, A., Irihimovitch, V., Dahan, I., Konrad, Z., and Eichler, J. (2006). Cloning, expression, and purification of functional Sec1la and Sec11b, Type I signal peptidases of the archaeon Haloferax volcanii. J. Bacteriol. 188, 1911-1919.

Ghosh, I., Hamilton, A. D., and Regan, L. (2000). Antiparallel leucine zipperdirected protein reassembly: application to the green fluorescent protein. J. Am. Chem. Soc. 122, 5658-5659. doi: 10.1021/ja994421w

Hofacker, A., Schmitz, K. M., Cichonczyk, A., Sartorius-Neef, S., and Pfeifer, F. (2004). GvpE- and GvpD-mediated transcription regulation of the p-gvp genes encoding gas vesicles in Halobacterium salinarum. Microbiology 150, 1829-1838. doi: 10.1099/mic.0.27078-0

Irihimovitch, V., and Eichler, J. (2003). Post-translational secretion of fusion proteins in the halophilic archaea Haloferax volcanii. J. Biol. Chem. 278, 1288112887. doi: 10.1074/jbc.M210762200

Knitsch, R., Schneefeld, M., Weitzel, K., and Pfeifer, F. (2017). Mutations in the major gas vesicle protein GvpA and impacts on gas vesicle formation in Haloferax volcanii. Mol. Microbiol. 106, 530-542. doi: 10.1111/mmi.13833

Krüger, K., Hermann, T., Armbruster, V., and Pfeifer, F. (1998). The transcriptional activator GvpE for the haloarchaeal gas vesicle genes resembles a basic leucinezipper regulatory protein. J. Mol. Biol. 279, 761-771. doi: 10.1006/jmbi.1998. 1795

Magliery, T. J., Wilson, C. G. M., Pan, W., Mishler, D., Ghosh, I., Hamilton, A. D., et al. (2005). Detecting protein-protein interactions with a green fluorescent protein fragment reassembly trap: scope and mechanism. J.Am. Chem. Soc. 127, 146-157. doi: $10.1021 / \mathrm{ja} 046699 \mathrm{~g}$

Morag, E., Lapidot, A., Govorko, D., Lamed, R., Wilchek, M., Bayer, E. A., et al. (1995). Expression, purification, and characterization of the cellulosebinding domain of the scaffolding subunit from the cellulosome of Clostridium thermocellum. Appl. Environ. Microbiol. 61, 1980-1986. doi: 10.1128/AEM.61. 5.1980-1986.1995

Offner, S., Hofacker, A., Wanner, G., and Pfeifer, F. (2000). Eight of fourteen gvp genes are sufficient for formation of gas vesicles in halophilic archaea. J. Bacteriol. 182, 4328-4336. doi: 10.1128/JB.182.15.4328-4336.2000

Offner, S., and Pfeifer, F. (1995). Complementation studies with the gas vesicle encoding p-vac region of Halobacteirum salinarium $\mathrm{PHH} 1$ reveal a regulatory
The students Gayathiri Thavayogarajah, Regine Knitsch, and Sergio Leftheriotis (TU Darmstadt) are thanked to supply some of the vectors used in this study. Valuable discussions with Johannes Born and Arnulf Kletzin (TU Darmstadt) are gratefully acknowledged.

\section{SUPPLEMENTARY MATERIAL}

The Supplementary Material for this article can be found online at: https://www.frontiersin.org/articles/10.3389/fmicb. 2020.610179/full\#supplementary-material

role for the p-gvpDE genes. Mol. Microbiol. 16, 9-19. doi: 10.1111/j.1365-2958. 1995.tb02387.x

Offner, S., Wanner, G., and Pfeifer, F. (1996). Functional studies of the gvpACNO operon of Halobacterium salinarium reveal that the GvpC protein shapes gas vesicles. J. Bacteriol. 178, 2071-2078. doi: 10.1128/jb.178.7.2071-2078.1996

Offner, S., Ziese, U., Wanner, G., Typke, D., and Pfeifer, F. (1998). Structural characteristics of halobacterial gas vesicles. Microbiology 144, 1331-1342. doi: 10.1099/00221287-144-5-1331

Ortenberg, R., and Mevarech, M. (2000). Evidence for post-translational membrane insertion of the intergral membrane protein bacterioopsin expressed in the heterologous halophilic archaeon Haloferax volcanii. J. Biol. Chem. 275, 22839-22846. doi: 10.1074/jbc.M908916199

Palmer, B. R., and Marinus, M. G. (1994). The dam and $\mathrm{dcm}$ strains of Escherichia coli - a review. Gene 143, 1-12. doi: 10.1016/0378-1119(94)90597-5

Pfeifer, F. (2012). Distribution, formation and regulation of gas vesicles. Nat. Rev. Microbiol. 10, 705-715. doi: 10.1038/nrmicro2834

Pfeifer, F., and Ghahraman, P. (1993). Plasmid pHH1 of Halobacterium salinarium: characterization of the replicon region, the gas vesicle gene cluster and insertion elements. Mol. Gen. Genet. 238, 193-200. doi: 10.1007/BF00279547

Pfeifer, F., Offner, S., Krüger, K., Ghahraman, P., and Englert, C. (1994). Transformation of halophilic archaea and investigation of gas vesicle synthesis. Syst. Appl. Microbiol. 16, 569-577. doi: 10.1016/S0723-2020(11)80327-9

Poole, D. M., Morag, E., Lamed, R., Bayer, E. A., Hazlewood, G. P., and Gilbert, H. J. (1992). Identification of the cellulose-binding domain of the cellulosome subunit S1 from Clostridium thermocellum YS. FEMS Microbiol. Lett. 99, 181186. doi: 10.1016/0378-1097(92)90022-G

Reuter, C. J., and Maupin-Furlow, J. A. (2004). Analysis of proteasome-dependent proteolysis in Haloferax volcanii cells, using short-lived green fluorescent proteins. Appl. Environ. Microbiol. 70, 7530-7538. doi: 10.1128/AEM.70.12. 7530-7538.2004

Schägger, H., and von Jagow, G. (1987). Tricine-sodium dodecylsulfatepolyacrylamide gel electrophoresis for the separation of proteins in the range from 1 to $100 \mathrm{kDa}$. Anal. Biochem. 166, 368-379. doi: 10.1016/0003-2697(87) 90587-2

Scheuch, S., and Pfeifer, F. (2007). GvpD-induced breakdown of the transcriptional activator GvpE of halophilic archaea requires a functional p-loop and an arginine-rich region of GvpD. Microbiology 153, 947-958. doi: 10.1099/mic.0. 2006/004499-0

Schlesner, M., Miller, A., Besir, H., Aivaliotis, M., Streif, J., Scheffer, B., et al. (2012). The protein interaction network of a taxis signal transduction system in a halophilic archaeon. BMC Microbiol. 12:272. doi: 10.1186/1471-2180$12-272$

Shukla, H. D., and DasSarma, S. (2004). Complexity of gas vesicle biogenesis in Halobacterium sp. strain NRC-1: identification of five new proteins. J. Bacteriol. 186, 3182-3186. doi: 10.1128/jb.186.10.3182-3186.2004

Sivertsen, A. C., Bayro, M. J., Belenky, M., Griffin, R. G., and Herzfeld, J. (2010). Solid-state NMR characterization of gas vesicle structure. Biophys. J. 99, 19321939. doi: 10.1016/j.bpj.2010.06.041

Strunk, T., Hamacher, K., Hoffgaard, F., Engelhardt, H., Zillig, M. D., Faist, K., et al. (2011). Structural model of the gas vesicle protein GvpA and analysis of GvpA mutants in vivo. Mol. Microbiol. 81, 56-68. doi: 10.1111/j.1365-2958. 2011.07669.x 
Tavlaridou, S., Winter, K., and Pfeifer, F. (2014). The accessory gas vesicle protein GvpM of haloarchaea and its interaction partners during gas vesicle formation. Extremophiles 18, 693-706. doi: 10.1007/s00792-0140650-0

Waaland, R. J., and Branton, D. (1969). Gas vacuole development in a bluegreen alga. Science 163, 1339-1341. doi: 10.1126/science.163.3873.1339

Walsby, A. E. (1994). Gas vesicles. Microbiol. Rev. 58, 94-144. doi: 10.1042/ bj2640313

Winter, K., Born, J., and Pfeifer, F. (2018). Interaction of haloarchaeal gas vesicle proteins determined by split-GFP. Front. Microbiol. 9:1897. doi: 10.3389/fmicb. 2018.01897

Xu, B. Y., Dai, Y. N., Zhou, K., Liu, Y. T., Sun, Q., Ren, Y. M., et al. (2014). Structure of the gas vesicle protein GvpF from the cyanobacterium Microcystis aeruginosa. Acta Crystallogr. D Biol. Crystallogr. 70, 3013-3022. doi: 10.1107/ S1399004714021312
Zimmermann, P., and Pfeifer, F. (2003). Regulation of the expression of the gas vesicle genes in Haloferax mediterranei: interaction of the two regulatory proteins GvpD and GvpE. Mol. Microbiol. 49, 783-794. doi: 10.1046/j.13652958.2003.03593.x

Conflict of Interest: The authors declare that the research was conducted in the absence of any commercial or financial relationships that could be construed as a potential conflict of interest.

Copyright (c) 2020 Völkner, Jost and Pfeifer. This is an open-access article distributed under the terms of the Creative Commons Attribution License (CC BY). The use, distribution or reproduction in other forums is permitted, provided the original author(s) and the copyright owner(s) are credited and that the original publication in this journal is cited, in accordance with accepted academic practice. No use, distribution or reproduction is permitted which does not comply with these terms. 